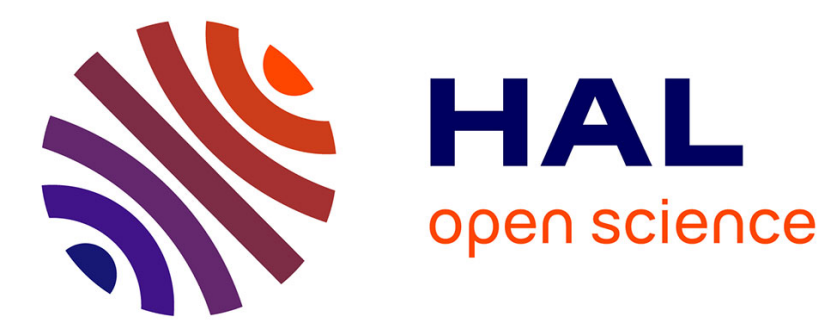

\title{
Slumping dynamics in tilled sandy soils under natural rainfall and experimental flooding
}

Hongtao Hao, Christian Hartmann, Jongskul Apichart, Siltacho Siwaporn, Sukanya Promsakha, Guy Richard, Ary Bruand, Anthony R. Dexter

\section{- To cite this version:}

Hongtao Hao, Christian Hartmann, Jongskul Apichart, Siltacho Siwaporn, Sukanya Promsakha, et al.. Slumping dynamics in tilled sandy soils under natural rainfall and experimental flooding. Soil and Tillage Research, 2011, 114 (1), pp.9-17. 10.1016/j.still.2011.03.004 insu-00589822

\section{HAL Id: insu-00589822 \\ https://hal-insu.archives-ouvertes.fr/insu-00589822}

Submitted on 2 May 2011

HAL is a multi-disciplinary open access archive for the deposit and dissemination of scientific research documents, whether they are published or not. The documents may come from teaching and research institutions in France or abroad, or from public or private research centers.
L'archive ouverte pluridisciplinaire HAL, est destinée au dépôt et à la diffusion de documents scientifiques de niveau recherche, publiés ou non, émanant des établissements d'enseignement et de recherche français ou étrangers, des laboratoires publics ou privés. 


\section{Slumping dynamics in tilled sandy soils under natural rainfall and}

\section{2 experimental flooding}

3 Hongtao Hao ${ }^{\mathrm{a}, \mathrm{b}}$, Christian Hartmann ${ }^{\mathrm{a}}{ }^{\text {, Jongskul Apichart }}{ }^{\mathrm{c}}$, Siltacho Siwaporn ${ }^{\mathrm{d}}$,

4 Sukanya Promsakha ${ }^{\mathrm{d}}$, Guy Richard ${ }^{\mathrm{b}}$, Ary Bruand ${ }^{\mathrm{e}}$, Anthony R. Dexter ${ }^{\mathrm{b}, \mathrm{f}}$

5

6 a Institut de Recherche pour le Développement (IRD), UMR 211 - Bioemco (Biogéochimie et Ecologie des Milieux

7 Continentaux), Ecole normale supérieure (ENS) - Laboratoire 'BIOEMCO', 46 rue d'Ulm - 75230, Paris, France

$8{ }^{b}$ Institut National de la Recherche Agronomique (INRA), UR 0272 Science du Sol, Centre de Recherche

9 d'Orléans, CS 40001 F-45075, Orléans, Cedex 2, France

$10{ }^{c}$ Land Development Department (LDD), Chatuchak, 10900, Bangkok, Thailand.

$11{ }^{d}$ Land Development Department (LDD), Regional Office No.5, Mittaphap road, Mueng district, 40000, Khon

12 Kaen, Thailand

$13{ }^{e}$ Université d'Orléans, CNRS/INSU, Institut des Sciences de la Terre d'Orléans (ISTO), UMR 6113, 1A Rue de la

14 Férollerie 45071, Orléans, France

15 Institue of Soil Science and Plant Cultivation (IUNG), ul. Czartoryskich 8, 24-100 Pulawy, Poland

16

171 Corresponding author

18 E-mail address: christian.hartmann@ird.fr

19 


\section{Abstract}

2 Compaction of tilled layers under the single effect of rainfall or irrigation was called slumping.

3 Slumping affects strongly root development and plant biomass production and was observed in

4 different soil types but sandy soils appear particularly prone to this physical degradation. Our

5 objectives in this study were (i) to monitor in the field the changes in soil structure and water status

6 simultaneously, (ii) to study the effects of rainfall and management practices on slumping and (iii)

7 to propose a conceptual model for sandy soil slumping.

8 An experimental site was selected in Northeast Thailand and we tested the effect of tillage

9 depth and initial water content on slumping dynamic. Plots $(9 \mathrm{~m} \times 15 \mathrm{~m})$ were tilled at (i) two depths

10 (20 and $40 \mathrm{~cm}$, called S and D respectively) in dry conditions, (ii) at $20 \mathrm{~cm}$ depth in dry or wet

11 conditions (called $\mathrm{Y}$ and $\mathrm{W}$ respectively). These plots were submitted to natural rainfall for 20 or

1261 days to get different total rainfall amounts (114 and $212 \mathrm{~mm}$ respectively). In addition, smaller

13 plots $\left(0.24 \mathrm{~m}^{2}\right)$ were used for experimental flooding irrigation (equivalent to measured rainfalls, i.e.

14100 and $200 \mathrm{~mm}$ ). Soil bulk density, soil surface elevation, soil water content and matric potential 15 were recorded.

16 A decrease in soil elevation was observed in all treatments. In the absence of erosion it was 17 interpreted as a loss of porosity which resulted from slumping. Bulk density increased in all layers 18 of the tilled profile (from 1.38 to $\left.1.57 \mathrm{~g} \mathrm{~cm}^{-3}\right)$. In the surface layer $(0-5 \mathrm{~cm})$ this increase was 19 systematically higher compared to deeper layer. No significant difference in final bulk density was

20 found between the $\mathrm{S}$ and $\mathrm{W}$ treatments, and between the $\mathrm{Y}$ and $\mathrm{W}$ treatments. Bulk density 21 increased more rapidly in the $\mathrm{Y}$ and $\mathrm{W}$ treatments than in the S and D treatments, even though the 22 cumulative rainfall was lower. After flooding experiments, bulk density was higher than after 23 natural rainfall despite similar water amount brought to the soil.

24 The existence of a layer with $50 \%$ porosity straight after tillage was explained by the capillary 
1 forces developed by water bridges between the elementary grains. Models of wet granular material

2 indicate that a drastic loss of cohesion can occur when the liquid phase becomes continuous.

3 Indeed slumping was observed during the downward movement of the water front inside the 4 profile which is consistent with this hypothesis. As the existence of a continuous liquid phase along 5 the profile is the most determinant factor of slumping, all rainfall characteristics determining the 6 existence of such a continuous liquid phase will affect slumping, i.e. rainfall intensity, duration and 7 frequency. For given rainfall characteristics, slumping dynamic and intensity depend on the bulk 8 density at the onset of the rainfall or irrigation event. The high variability recorded in earlier field 9 result from the many possible interactions between these determining factors.

11 Keywords: Recompaction; Bulk density; Matric potential; Northeast Thailand; Tillage;

12 Overburden pressure 


\section{Introduction}

Soil tillage aims at creating favorable physical conditions for crop growth by modifying the soil structure and associated properties of the tilled layer (Guérif et al., 2001). However, the desired loose structure tends to be structurally unstable and is susceptible to structural collapse thus leading to a loss of the benefits for root development provided by soil (Hartmann et al., 2008a; Hamza and Anderson, 2005). Soil recompaction (i.e. bulk density increase to initial level) is a general phenomenon which has several causes related to external and internal forces. External force is defined as loading from outside the soil profile, such as tractor loading, rainfall kinetic energy; internal force is defined as force inside the soil profile, such as overburden pressure, capillary force. Soil recompaction is commonly attributed to mechanized agriculture alone because the weight of the agricultural and forestry machinery has been increased three- to fourfold as well as the frequency of wheeling during recent decades (e.g. Soane et al., 1981a, b; Soane et al., 1982; Soane, 1990; Horn et al., 1995; Soane and Van Ouwerkerk, 1995; Soane and Ball, 1998; Hamza and Anderson, 2005). The phenomenon of bulk density increase recorded after wetting and without application of any external load was termed 'slumping' (Kemper and Rosenau, 1984; Mullins et al.1990). While compaction, i.e. the bulk density increase resulting from mechanical loading was widely studied, much less attention has been paid to slumping.

For coarse-textured soils, Kemper and Rosenau (1984) suggested that slumping is related to soils saturation or matric potential $\psi$ close to $0 \mathrm{hPa}$. Slumping is a ubiquitous phenomenon and was recorded under a wide range of conditions. It was recorded after a single rainfall event $(20 \mathrm{~mm}$ in one hour) (Mead and Chan, 1988), two natural rainfall events (80 mm in $160 \mathrm{~min}$ ) (Hartmann et al., 1999), eight weeks of measuring (Osunbitan et al., 2005), and a cropping season (Hamblin and Tennant, 1979). Moreover, slumping can affect the whole tilled layer (such as down to $40 \mathrm{~cm}$ depth in Moffat and Boswell, 1997), and can have similar adverse effects on crop development as well as 
1 compaction resulting from mechanical loading (Kozlowski, 1999). Despite its ubiquity and

2 importance, no study has provided yet a detailed description of the dynamics of slumping and its

3 main field characteristics. In the context of the extension of cultivated lands to marginal areas,

4 which often include a high proportion of sandy soils (Eswaran et al., 2007), it is a challenge to look

5 for soil management that could minimize the occurrence of slumping. As a first step in this

6 direction, the objectives of our study were: (i) to monitor the changes in soil structure and water

7 status simultaneously at the field scale; (ii) to study the effects of rainfall and management

8 practices on slumping and iii) to propose a conceptual model of sandy soil slumping.

10 2. Material and Methods

\section{$11 \quad$ 2.1. Field description}

12 Northeast Thailand is a sandy alluvial plateau covered by an aeolian deposit (approximately

$131 \mathrm{~m}$ thick) mainly made of quartz grains. More than $80 \%$ of the grains belong to the sand fraction $14(50-2000 \mu \mathrm{m})$ and about 10\% to the silt fraction $(2-50 \mu \mathrm{m})$ (Lesturgez et al., 2004; Bruand et al., 15 2004). The clay fraction $(<2 \mu \mathrm{m})$ is less than $10 \%$ and contains phylosilicates (mainly kaolinite and 16 small amount of smectite) but also quartz grains (Bruand et al., 2004). An experimental site was 17 selected in a village named Baan Nong Sang (WGS84: $16^{\circ} 10^{\prime} \mathrm{N}, 102^{\circ} 48^{\prime} \mathrm{E}$ ), $30 \mathrm{~km}$ south of the 18 city of Khon Kaen. The soil is representative of the region with a sandy texture ( $<4 \%$ clay), low

19 organic matter content $\left(<5 \mathrm{~g} \mathrm{~kg}^{-1}\right)$ and high bulk density $\left(\rho_{\mathrm{b}} \geq 1.6 \mathrm{~g} \mathrm{~cm}^{-3}\right)$ (Table 1 and 2$)$. This field 20 was planted with cassava in 2006 and harvested in February 2007. To minimize the effect of coarse 21 crop residues fragments (cassava branches and leaves, weeds, etc.) on the different soil physical 22 characteristics, they were removed from the plot before tillage operations. To prevent weed growth, 23 an herbicide was applied three times during the experiment. 
2 Three experiments were conducted at different periods to get different rainfall distribution and 3 rainfall amount:

4 - Experiment 1 (Exp. 1): plots were tilled on 25 May, i.e. at the beginning of the rainy season that is generally characterised by storms separated by several dry days. The experiment was stopped on 1 August; - Experiment 2 (Exp. 2): plots were tilled on 6 July, i.e. in the middle of the rainy season to get a different rainfall pattern (more regular distribution of the rainfalls and thus less frequent dry that installed inside the experimental field.

The objective of Exp. 1 was to study the effect of tillage depth on slumping characteristics. Soil preparation treatments consisted of two tillage depths: 20 and $40 \mathrm{~cm}$, called shallow (S) and deep

19 (D) treatments respectively. Each treatment was applied to five elementary plots $(9 \mathrm{~m} \times 15 \mathrm{~m}$ each).

20 Tillage was performed using a 120-horse-power tractor equipped with a set of disk plough. In order

21 to increase the homogeneity of the resulting soil structure, the large clods left by mechanical tillage 22 were broken into smaller pieces by labourers using rakes. To mimic the practice of farmers who 23 want to avoid flooding of the seed rows, ridges were built by hand two days after tillage. The 24 interval between ridges was $40 \mathrm{~cm}$ and their height ranged from 12 to $17 \mathrm{~cm}$. 
MonitorMeasuring days were identified by the number of days after ploughing (DAP, thus

2 DAP 0 meaning the 25 May) and by accumulated rainfall (AR in $\mathrm{mm}$ ) since DAP 0 . Soil water

3 potential was measured using a set of ceramic tensiometers each equipped with an electronic

4 transducer (model 2150 and SMS-2500S, SDEC Company, France). They were installed at $5 \mathrm{~cm}$

5 intervals from 10 to 20 or $40 \mathrm{~cm}$ depth according to tillage depth in two different locations:

6 underneath either the ridge or the furrow. The zero level (soil surface) was counted from the surface

7 of the ridge or the furrow according to the location of the tensiometer. Two sets of tensiometers

8 were installed for each treatment (S and D) as replicates. Water matric potential $(\psi)$ was measured

9 after each major rainfall event or after 3 to 7 days if no rainfall event occurred.

10 Changes in soil level were measured using a horizontal frame as a stable benchmark. It 11 consisted of a $1 \times 1 \mathrm{~m}^{2}$ frame horizontally put on four metallic rods inserted $70 \mathrm{~cm}$ below the soil 12 surface and fixed by cement. The distance between the frame and the soil surface was measured 13 using a laser beam (Lasermeter Leica Disto 6A, Leica Geosystem, Switzerland) according to a $145 \times 5 \mathrm{~cm}^{2}$ grid (total of 361 data points). The vertical precision was $1 \mathrm{~mm}$. For both treatments (D 15 and S), replicates were installed in three of the five elementary plots. To measure changes in $\rho_{b}$ and 16 soil water content $(W c)$, after each major rainfall event, undisturbed cylinders of soil $(5 \mathrm{~cm}$ in 17 height and diameter) were collected every $5 \mathrm{~cm}$ in depth under furrows. They were weighted before 18 and after putting in an oven for $24 \mathrm{~h}$ at $105^{\circ} \mathrm{C}$

\subsection{Experiment 2}

21 The objective of Experiment 2 was to study the effect on slumping of the water content at 22 tillage. Five plots $\left(9 \times 15 \mathrm{~m}^{2}\right)$ were left under rainfall, while five other plots were protected from 23 rainfall using greenhouses. These greenhouses were built with bamboo sticks and covered by 24 plastic sheets $(0.8 \mathrm{~m}$ high); to avoid overheating and water condensation, they were opened at both 
1 ends so that air could circulate. To prevent preferential water infiltration along the plots, rainwater

2 falling on the surface of greenhouses was drained out of the field. The greenhouses were removed

3 on the 6 July and water content was measured after putting the soil sample in an oven for $24 \mathrm{~h}$ at

$4 \quad 105^{\circ} \mathrm{C}$.

5 The soil was tilled on the 6 July (DAP 0), at one depth only $(20 \mathrm{~cm})$ using the same tractor as in

6 Exp. 1. Therefore the treatments consisted in two different $W c$ during tillage; the treatments were

7 named 'dry' (Y) (plots under greenhouse before tillage) and 'wet' (W) (plots that were submitted to

8 rainfall before tillage). Five replicates were used for each treatment. Ridges and furrows were

9 prepared using the same procedure as in Exp. 1.

10 In both treatments ( $\mathrm{Y}$ and $\mathrm{W}$ ), a set of four tensiometers was installed below the furrow at $5 \mathrm{~cm}$

11 intervals from 10 to $25 \mathrm{~cm}$ depth. Changes in soil level were measured using a $1 \mathrm{~m}$ long horizontal

12 board as a stable benchmark, which was supported by metallic rods as "legs" inserted into soil at

$1370 \mathrm{~cm}$ depth as in Exp. 1. One replicate of this device was installed in each of the ten subplots. The

14 distance from the benchmark to the soil surface was measured using the laser beam every $2.5 \mathrm{~cm}$

15 (total of 38 data points). The $\rho_{\mathrm{b}}$ and $W c$ were measured using the same procedure as in Exp. 1.

\section{2.5. Experiment 3}

18 The objective was to mimic a continuous rainfall and to measure the consequences on slumping

19 characteristics. Three supplementary plots were covered by greenhouses to keep the soil dry.

20 Metallic rings $(55 \mathrm{~cm}$ in diameter) were inserted deeply in the soil $(60 \mathrm{~cm})$ to be used as stable

21 benchmark for soil level recording. The soil inside the ring was hand tilled using a small paddle and

22 rake to mimic the soil tractor tillage and hand raking as in Exp. 1 and 2. Soil preparation treatments

23 consisted of two tillage depths: 20 and $40 \mathrm{~cm}$, called "shallow-tillage flooding" (Sf) and

24 “deep-tillage flooding” (Df) respectively. Three rings were installed for each treatment. Unlike Exp. 
11 and 2, the soil surface was flat (no ridges and furrows were built). Tensiometers were not used

2 because the time was too short to obtain a good equilibrium between tensiometer and soil.

3 The amount of added water was $100 \mathrm{~mm}$ and $200 \mathrm{~mm}$ for Sf and Df treatments respectively.

4 The soil surface was covered by a straw textile and water was added by increments of $25 \mathrm{~mm}$ water.

5 To avoid kinetic energy, the water was poured on a hand as a buffer so that it gently felt on the

6 textile over the whole surface. Infiltration time was recorded and after each addition of $25 \mathrm{~mm}$

7 water, the soil surface level was measured every $5 \mathrm{~cm}$ along a horizontal "board" that was put on

8 the top of the metallic ring (10 measurement points each time) using the lasermeter. After the last

9 addition of water and measurement of soil level, a small pit was opened inside the ring. The bulk

10 density and water content were measured with $5 \mathrm{~cm}$ interval from surface to 20 and $40 \mathrm{~cm}$ depth in

11 Sf and Df respectively. Three replicates samples were taken inside each ring.

12

13 2.6. Statistical analysis

14 The data were analyzed statistically using ANOVA by SPSS 13.0 (SPSS Inc., 2004). The least 15 significant difference (LSD) at $P=0.05$ was used to establish the significance of differences 16 between treatment means. When applicable, paired-samples T tests were done.

\section{3. Results}

\section{3.1. Rainfall characteristics}

20 Fig. 1 presents the daily rainfall events and the accumulated rainfall (AR). During 61 days for 21 Exp. 1, AR was $212 \mathrm{~mm}$, approximately twice as much as in Exp. 2 (114 mm) which lasted only 2220 days. Exp. 2 was done during the middle of the rainy season and had higher average daily 23 rainfall than Exp. 1 which started earlier: 5.7 and $3.4 \mathrm{~mm} \mathrm{~d}^{-1}$, respectively. More than half of AR in 24 Exp. 2 resulted from two successive big rainfall events (22 and $36 \mathrm{~mm}$ ) which occurred at the end 
1 of the experiment.

\subsection{Experiments 1 and 2}

\subsubsection{Soil matric potential ( $\psi)$ and water content (Wc)}

For Exp. 1 and Y treatment (dry protected plots) in Exp. 2, Wc was ranging 0.04 to $0.06 \mathrm{~g} \mathrm{~g}^{-1}$; or

6 W (unprotected wet plots) in Exp. 2, Wc was significantly higher $(\mathrm{p}<0.05)$, ranging 0.08 to $0.10 \mathrm{~g}$ $7 \quad \mathrm{~g}^{-1}$ (data not shown).

Fig. 2 presents the matric potential $(\psi)$ measured under furrows and ridges in Exp. 1 (D

9 treatment), under furrows in Exp. 2 (W treatment). During Exp. 1, minimum and maximum matric 10 potential (i.e. driest and wettest soil respectively) were -120 and $-40 \mathrm{hPa}$ respectively. No

11 significant difference was observed between tensiometers installed under a furrow or under a ridge, 12 and no significant difference was observed between the $\mathrm{D}$ and $\mathrm{S}$ treatments (data not presented). At 13 a given time, we recorded similar minimum and maximum $\psi$ in Exp. 1 and Exp. 2. Moreover, no 14 differences were observed with the $\mathrm{W}$ and $\mathrm{Y}$ treatments compared with the $\mathrm{D}$ treatment in the $0-20$ $15 \mathrm{~cm}$ layer (data not presented).

16 In the top layers $(0-20 \mathrm{~cm})$, a rapid increase in $\psi$ was observed after rainfall events (e.g. DAP 1741 and DAP 58), but a slow and regular $\psi$ decrease was observed during the different dry spells (e.g. 18 from DAP 47 to 51). In the $35 \mathrm{~cm}$ layer, changes were buffered: the $\psi$ was significantly affected 19 only by the two successive big rainfall events recorded at the end of the experiment (DAP 59 and 2060,22 and $36 \mathrm{~mm}$ respectively).

21 For Exp. 1 and 2, it is noteworthy that at the end of the experiments (DAP 59 and 60), the 22 highest $\psi$ at $10 \mathrm{~cm}$ depth was recorded after the first rainfall event (-40 and $-50 \mathrm{hPa}$ respectively in 23 the top layer) while higher $\psi$ was expected after the second rainfall event (approximately twice as 24 much water input as the first event). This discrepancy is a consequence of manual monitoring: at 
1 DAP 59, $\psi$ was recorded shortly $(<1 \mathrm{~h})$ after the rainfall event; while at DAP 60, it was recorded

2 more than $10 \mathrm{~h}$ after the rainfall event. For the latter, the water front had already drained deeper in

3 the profile as indicated by the drastic increase in $\psi$ in the $35 \mathrm{~cm}$ deep layer, an increase which was

4 not observed after the first rainfall.

5 At the end of the experiment, in all plots, whatever the initial Wc at the tillage depth, Wc ranged

6 from 0.08 to $0.13 \mathrm{~g} \mathrm{~g}^{-1}$ (data not shown). There was no significant difference between D and S, and

7 between $\mathrm{Y}$ and $\mathrm{W}$.

\section{$9 \quad$ 3.2.2. Soil surface elevation and bulk density}

10 After each major rainfall event, a decrease in soil roughness was observed: the height of ridges

11 decreased while furrows were filled with sandy material, and consequently the field became more

12 flat (Fig. 3). This change in the topography of the soil surface indicated movements of solid 13 particles from the top of ridges to the bottom of furrows, but we didn't observe any erosion 14 (particles moving outside the field). The average soil level was calculated for the different 15 treatments (Fig. 4). A level decrease was observed in all plots (ranging from 1.2 to $1.7 \mathrm{~cm}$ ), but no 16 significantly difference was found between the different treatments.

17 Average $\rho_{\mathrm{b}}$ profiles under furrows are shown in Fig. 5. Immediately after tillage, all profiles 18 were characterised by a regular increase with depth. For shallow tillage (S, Y, W treatments, $20 \mathrm{~cm}$ 19 depth), the differences between $\rho_{\mathrm{b}}$ at top and bottom of tilled layer ranged from 0.05 to $0.10 \mathrm{~g} \mathrm{~cm}^{-3}$.

20 For deep tillage (D treatment, $40 \mathrm{~cm}$ depth), this increase was higher $\left(0.15 \mathrm{~g} \mathrm{~cm}^{-3}\right)$ indicating an 21 effect of tillage depth. When the soil was tilled in dry conditions (S, D and Y treatments), a shift 22 towards higher $\rho_{b}$ values was observed at all depths with increasing AR. Initial bulk density in the 23 profile was already higher when ploughing was performed at wet conditions. The shift was higher 24 in the top layer then in deeper layers. When the soil was tilled in wet conditions (W treatment), no 
1 change in $\rho_{b}$ was observed in relation with increasing AR, except in the top layer $(0-5 \mathrm{~cm})$ at the

2 end of the experiment.

$4 \quad$ 3.3. Experiment 3

5 During the first addition, the infiltration rate was 450 and $600 \mathrm{~mm} \mathrm{~h}^{-1}$ for Sf and Df respectively

6 (Fig. 6a). During the following additions, IR decreased until it was stabilised around $100 \mathrm{~mm} \mathrm{~h}^{-1}$.

7 The same value was observed in both treatments, suggesting that tillage depth did not influence the

8 infiltration rate. For the first three water inputs, the sinkage rate increased at each input $(-1.0,-1.2$,

$9-1.4 \mathrm{~cm}$ in Df treatment) (Fig. 6b). For all the following water inputs it decreased continuously

10 (from $0.6 \mathrm{~cm}$ with $100 \mathrm{~mm}$ input to $0.1 \mathrm{~cm}$ with $200 \mathrm{~mm}$ input in Df treatment). Tillage depth

11 affected the soil level decrease: at $100 \mathrm{~mm}$ water input, it was only $2.7 \mathrm{~cm}$ for Sf compared to

$124.2 \mathrm{~cm}$ for Df treatment. Just after tillage, $\rho_{\mathrm{b}}$ profile increased with depth: at the bottom of the tilled

13 layer $\rho_{\mathrm{b}}$ was about $0.3 \mathrm{~g} \mathrm{~cm}^{-3}$ higher than at the surface (Fig. 7). At the end of the experiment, for

14 both Df and Sf, $\rho_{b}$ shifted to higher values on all the profile, $\rho_{b}$ being higher close to the surface

15 than at the bottom (about 0.5 and $0.2 \mathrm{~g} \mathrm{~cm}^{-3}$ respectively).

\section{Discussion and conclusion}

18

19

20

21

22

23

\subsection{Evidence of slumping}

The soil surface reorganisation which was recorded during Exp. 1 and 2 and which consisted in a decrease in the soil roughness (Fig. 3) was commonly observed in coarse-textured soils and discussed as closely related to their low structural stability when submitted to rainfall (Mwendera and Feyen, 1994; Rudolph et al., 1997; Twomlow and Bruneau, 2000). Our results show that soil reorganisation affected not only surface but also the whole tilled horizon. In the three experiments 
1 and whatever the treatment, a soil sinkage was recorded, i.e. a decrease in soil surface elevation

2 (Fig. 4 and Fig. 6b). As no erosion was observed during the experiment (i.e. no mass movement out

3 of the field), such an elevation decrease in soil surface necessarily resulted from a loss of pore

4 volume, i.e. from an increase in soil compactness. Soil sinkage did not happen regularly over time

5 but was related to the occurrence of rainfall events, and consequently can be considered as an

6 indicator of soil slumping as defined by Mullins et al. (1990). Soil sinkage cannot be observed by

7 the naked eye even if it is probably a common phenomenon in coarse textured soils, thus explaining

8 the rarity of its description (Wilton, 1964; Young et al., 1991; Moffat et al., 1997; Or and Ghezzehei,

9 2002). Even if soil sinkage is a relevant indicator of slumping occurrence, it does not provide any

10 information about how compactness evolves with depth in the soil.

\subsection{Soil structure after tillage}

13 After tillage, the $\rho_{\mathrm{b}}$ profile presents two striking aspects. First, the $\rho_{\mathrm{b}}$ increased regularly with 14 depth (from $1.26 \mathrm{~g} \mathrm{~cm}^{-3}$ at surface to $1.44 \mathrm{~g} \mathrm{~cm}^{-3}$ at $40 \mathrm{~cm}$ depth), thus indicating a closer packing 15 of the soil particles when going deeper in the profile (Fig.5 and 7). Second, the $\rho_{b}$ values 16 (correspond to porosity ranging from 53 to 45\%) were very low in sandy soils since it results 17 mainly from the packing of coarse grains.

18 This loose packing was created by tillage: the energy developed by the disks was enough to 19 separate most elementary particles which were lifted up, increasing their potential energy. This 20 energy was dissipated when the particles moved downward under the effect of gravity. During the 21 piling process, each time a contact occurred between neighbouring particles, the downward 22 movement was hampered due to (i) mechanical friction, and (ii) capillary bridges developing 23 between the grains. At $W c<0.12 \mathrm{~g} \mathrm{~cm}^{-3}$, as measured before tillage (data not presented), water can 24 be located only at the contact points between two particles, forming bridges (Willet et al., 2000; 
1 Adams et al., 2002; Herminghaus, 2005). These bridges act as glue bonding the particles together

2 in relation with the water interfacial tension and negative Laplace pressure (Kemper and Rosenau,

3 1984). The development of water bridges hampered the flow of solid particles and blocked the sand

4 grains into a loose packing. But during the piling process, the overburden pressure was gradually

5 increasing with depth, forcing the grains to rearrange in a continuously closer packing, resulting in

6 a regular $\rho_{\mathrm{b}}$ increase with depth. This could be a general behaviour in tilled sandy soils (Ampoorter

7 et al., 2007). The stability of the tilled layer results from capillary bridges and is consequently low,

8 but in the absence of mechanical loading, it is stable until occurrence of rain and subsequent

9 slumping.

\section{4.3. Water characteristics inducing slumping}

12 No relation was found between rainfall amount and slumping characteristics (occurrence, 13 intensity, dynamic): (i) slumping was triggered by a small but variable amount of water (34 $\mathrm{mm}$ in 14 Exp. 2 but only $25 \mathrm{~mm}$ in Exp. 3), (ii) despite similar large amounts of water brought to the soil 15 ( 200 mm), the intensity of slumping was much higher in Exp. 3 than in Exp.1 (soil sinkage of 4.6 16 and $1.2 \mathrm{~cm}$ respectively), (iii) when at the end of Exp.1 and 2, AR were very different (200 $\mathrm{mm}$ and $17100 \mathrm{~mm}$ respectively), intensity of slumping was similar, i.e. same final $\rho_{\mathrm{b}}\left(>1.4 \mathrm{~g} \mathrm{~cm}^{-3}\right.$ below $1810 \mathrm{~cm}$ ), and (iv) slumping was faster in Exp. 3 compared to Exp 1 (nearly finished after $75 \mathrm{~mm}$ 19 water input in Exp. 3 when still observed after $132 \mathrm{~mm}$ water input in Exp.1) (Fig. 5).

20 The lack of a global relation between slumping and rainfall characteristics, suggests that not all 21 rainfall events have the same potential to induce slumping. A soil material is stable as long as it meets the Mohr-Coulomb criterions: 
1 where $\tau$ is the shear stress, $\sigma$ is the normal force, $\mu$ is the internal friction coefficient and $\mathrm{c}$ is

2 cohesion. The cohesion is equivalent to the shear stress at zero normal force and it depends on (i)

3 both the amount and type of clay and organic matter (i.e. permanent bonds), and (ii) the water

4 content (Le Bissonnais et al., 1995). Sandy soils have low clay and organic carbon content,

5 consequently water becomes a major factor of cohesion between the elementary particles and

6 globally of structural stability (Panayiotopoulos and Mullins, 1985, Panayiotopoulos, 1989).

7 Kemper et Rosenau (1984) suggested that slumping was related to soil saturation and resulting lack

8 of cohesion between the elementary particles. Recent development on the physics of wet granular

9 material, like sandy soils, suggest that slumping would occur before reaching water saturation.

10 Indeed, in a sandy material, the relation between soil cohesion and water content is not linear,

11 two successive stages need to be considered (Pierrat and Caram, 1997; Iveson et al., 2002; Mitarai

12 and Nori, 2006): at the first stage, water is located only at the contact between grains and is filling

13 the packing pores between neighbouring grains creating separated clusters of grains (Kohonen et

14 al., 2004; Scheel et al., 2008). The second stage starts after all the packing pores were filled with

15 water when the liquid phase becomes continuous (Herminghaus, 2005). The second stage is

16 characterised by a drastic decrease in development of air/water interfaces and thus a drastic

17 drecrease in macroscopic cohesion (Soulié et al., 2006; Grof et al., 2008). Such a model suggests

18 that slumping in sandy soils would be triggered before reaching saturation, when rainfall amount is

19 high enough to obtain a continuous liquid phase draining down in the profile. Compared to natural

20 tilled sandy soil, the experimental and mathematical models studied by physicists are simplified

21 (the particles size distribution is limited and the grains are in close packing). Even so, it is still a

22 challenge to determine Wc or $\psi$ that corresponds to a continuous liquid phase in these models and it

23 is not yet possible for real soils. Anyway, such liquid phase continuity in sandy material can be

24 observed during fast downward movement of the wetting front that correspond to a locally high Wc 


\subsection{Slumping dynamics and water infiltration}

In Exp.3 water supply was continuous, creating an infiltration and thus a downward movement of the wetting front. Soil and water characteristics were recorded during and immediately after

$6(<1 \mathrm{~h})$ water supply. During the first water input, soil surface sinkage (indicating a rearrangement of

7 elementary grains) was observed; sinkage intensity increased until the third addition of water, then

8 it decreased again and even if it was small, sinkage was observed until the last water input (Fig. 6b).

9 This result confirms that slumping occurred during the downward movement of the wetting front,

10 i.e. before saturation, contrary to the suggestion of Kemper and Rosenau (1984). Similar fast

11 rearrangement was already recorded in an independent field experiment during which the largest $\rho_{b}$

12 increase occurred within the first 10 min of rainfall (Bedaiwy and Rolston, 1993).

13 Exp. 1 and 2 were conducted under natural rainfall events and were characterised by slower

14 slumping dynamic. Soil and water characteristics $\left(\rho_{\mathrm{b}}, \psi, W c\right)$ were monitored manually at the 15 interval of one to seven days; consequently our device could not record any fast water front 16 movement. Anyway, structural changes (soil surface sinkage and bulk density increased) were 17 observed only after the limited number of major rainfall events, events that occurred similarly

18 during Exp. 1 and 2 (Fig. 1). This observation is consistent with the hypothesis that all rainfall 19 events do not have the same capability to induce slumping; in the context of our experiment, only 20 events $>15 \mathrm{~mm}$ induced fast wetting front infiltration and significant structural changes (surface 21 level decrease, bulk density increase).

22 In Exp. 3, a steady state was reached earlier for infiltration rate than for soil elevation decrease 23 (Fig. 6a and Fig. 6b). This suggests that infiltrability is not a good indicator of slumping (direct 24 observations of structural changes have to be preferred). On the other hand, these data can also 
1 provide some indications on the characteristics of sand grains rearrangement at the onset of the first

2 major rainfall. The steady state observed for infiltration when slumping was still on process

3 indicates that the continuity of the porosity (a major factor of infiltration rate) decreased faster than

4 total pore volume (Nimmo and Akstin, 1988; Meek et al., 1992). In a pile of grains that results from

5 a loose packing of grains linked together only by capillary water bridges, the first grains to be

6 unbalanced are probably the biggest ones. They are indeed the most strongly pulled by gravity and

7 less strongly hold by capillary bridges. Once unbalanced, those grains can 'fall' in the large pores

8 (with $50 \%$ porosity, the volume occupied by porosity is the same as occupied by particles). This

9 reorganisation would explain the fast infiltration decrease related to (i) a decrease in the volume of

10 large pores (i.e. that allows fast water movement), and (ii) a decrease in the continuity of the

11 remaining smaller packing pores.

12

13 4.5. Soil factors affecting slumping

14 Previous experiment demonstrated that under similar rainfall events, slumping could differ in 15 relation with soil management (Meek et al., 1988; Bedaiwy and Rolston 1993, Hartmann et al, $162008 a, b)$. Our experiment confirmed that the relative change of $\rho_{b}$ was inversely correlated with the 17 initial $\rho_{\mathrm{b}}$ as already suggested by Bedaiwy and Rolston (1993). For exemple, compared to the 18 shallow layers, the deep layers had the highest $\rho_{b}$ after tillage, and they had also the smallest $\rho_{b}$ 19 increase during the experiment. Less slumping was also observed when the soil was initially wet 20 compared to when it was initially dry (Fig. 6). As the wet sandy soils are more sensitive to 21 mechanical stresses than dry soils (Panayiatopoulos et al., 1989; Meek et al., 1992), during the 22 tillage operations the $\mathrm{W}$ plots were probably more affected by mechanical constraints induced by 23 the disk than the Y plots. This suggests that the factor hampering the slumping process in $\mathrm{W}$ 24 compared to Y treatment was its higher initial $\rho_{\mathrm{b}}$ and not its higher Wc. 
While inside the profile, the relative $\rho_{b}$ change was inversely correlated to the initial $\rho_{b}$, the top

2 layer behaved differently: $\rho_{b}$ increase was constant and was finally huge compared to the

3 underlying layers. In first estimate, a different behaviour of the top layer seemed to be related to a

4 lateral sand movement from the ridge and accumulation on the surface of the furrow (Exp.1 and 2,

5 Fig. 3). But similar increase was recorded in Exp. 3 which had a flat surface and where no lateral

6 movement occurred. On a flat surface, the soil structure can also be degraded by vertical

7 segregation of clay and sand fractions due to the kinetic energy of the raindrops and result in

8 different surface crusts (Casenave and Valentin, 1992). Such crusts are only some millimeters thick

9 (Bielders and Bavey, 1995; Roth, 1997; Fohrer et al., 1999; Ndiaye et al., 2005) and cannot explain

10 changes at several centimeters depth and deeper in the tilled layer. Indeed, the surface layer is

11 characterised by (i) a very small normal force $\sigma$ (Eq (1)) due to quasi absence of overburden

12 pressure, and (ii) a frequent occurrence of high $\mathrm{Wc}$, even during minor rainfall events. These two

13 specific characteristics can explain that the particle reorganisation at the surface is different from

14 that observed below the surface layer.

15 Since surface heterogeneity can induce preferential water infiltration (Twomlow and Bruneau,

16 2000), the presence of ridges and furrows has to be mentionned: slumping was perhaps also

17 influenced by that specific surface topography, but we have not collected any data that allows a

18 estimation on the effect of this factor .

\subsection{A conceptual model of soil slumping}

21 When Kemper and Rosenau (1984) and Mullins et al. (1990) suggested the existence of a 22 specific degradation process named slumping, they did not provide any information about its

23 kinetic, and the underlying processes and determinant factors. Here we suggest a scenario of 24 slumping in sandy soils and a list of determinant factors based on our experiment. Slumping kinetic 
1 can be separated in three main steps (Fig. 8): (i) creation of an initial loose profile with a regular $\rho_{b}$

2 increase with depth after tillage, the cohesion and stability of these layers resulting from the strong

3 capillary forces between elementary grains (Fig. 8-a), (ii) during major rainfall events or under

4 irrigation, a fast increase in $\rho_{b}$ in all tilled layers, the loss of cohesion resulting from the

5 development of a continuous (but transient) liquid phase along the profile (Fig. 8-b), and (iii) after

6 each major rainfall, when the soil is gradually getting denser, the slumping intensity is decreasing

7 because of steric constraints to reorganisation, except for the surface layer where bulk density

8 seems to be continuously increasing (Fig. 8-c). As the existence of a continuous liquid phase along

9 the profile is the most determinant factor of slumping, all rainfall characteristic determining the

10 existence of such continuous liquid phase will affect slumping, i.e. rainfall intensity, duration and

11 frequency. For given rainfall characteristics, slumping dynamic and intensity depends on the bulk

12 density at the onset of the rainfall or irrigation event. The high variability recorded in earlier field 13 works (for example: Mead and Chan, 1988; Meek et al., 1988, Hartmann et al., 1999 ; Osunbitan et 14 al., 2005) result from the many possible interactions between these determining factors.

15 Further experiments should include a better control of experimental conditions associated to 16 more accurate recording at the time scale of the rainy events to obtain new data enabling to 17 establish a quantitative model and consequently improve our knowledge and prevision of the 18 elementary mechanisms of slumping.

\section{Acknowledgements}

21 The authors thank the support from Ms Wanpen Wiriyakitnateekul and Ms Nopmanee Suvannang 22 (LDD, Land Development Department, Thailand); and the help from Mr. Jean-Luc Maeght, Dr 23 Claude Hammecker, Dr Christian Valentin (IRD, Institut de Recherche pour le Développement, 24 France); Ms. Tum Nitjaporn Kunklang, Mr. Worraphan Chintachao. We thank Frédéric Darboux 
1 and David Lees for helpful comments and improving the English. We thank the anonymous

2 reviewers and the editors for their very useful suggestions to improve the manuscript. Hongtao Hao

3 thanks IRD for the financial support that made his study of $\mathrm{PhD}$ in France possible. He also thanks

4 the constant support from Prof. SUN Bo and Prof. ZHAO Qiguo (Institute of Soil Science, Chinese

5 Academy of Sciences, China).

6

7

8

\section{References}

Adams, M., Johnson, S., Seville, J., Willett, C., 2002. Mapping the influence of gravity on pendular liquid bridges between rigid spheres. Langmuir, 18, 6180-6184.

Ampoorter, E., Goris, R., Cornelis, W.M., Verheyen, K., 2007. Impact of mechanized logging on compaction status of sandy forest soils. For. Ecol. Manage. 241, 162-174.

Bedaiwy, M.N., Rolston, D.E., 1993. Soil surface densification under simulated high intensity rainfall. Soil Technol. 6, 365-376.

Bielders, C.L. and Baveye, P., 1995. Processes of structural crust formation on coarse-textured soils. Eur. J. Soil Sci. 46, 221-232.

Bruand, A., Hartmann, C., Ratana-Anupap, S., Sindhusen, P., Poss, R., Hardy, M., 2004. Composition, fabric, and porosity of an arenic haplustalf of Northeast Thailand: Relation to penetration resistance. Soil Sci. Soc. Am. J. 68, 185.

Casenave, A., Valentin, C., 1992. A runoff capability classification system based on surface features criteria in semi-arid areas of West Africa. Journal of Hydrology, 130, 231-249.

Eswaran, H., Vearasilp, T., Reich, P., Beinroth, F., 2007. Sandy soils of Asia: A new frontier for agricultural development., Proceedings of Management of Tropical Sandy Soils for Sustainable Agriculture: A Holistic Approach for Sustainable Development of Problem Soils 
in the Tropics, KhonKaen, Thailand, FAO Regional Office Bangkok, pp. 22-30.

2 Fohrer, N., Berkenhagen, J., Hecker, J.M. \& Rudolph, A. 1999. Changing soil and surface conditions during rainfall. Single rainstorm/subsequent rainstorms. Catena, 37, 355-375.

4 Grof, Z., Lawrence, C.J., Stepánek, F., 2008. The strength of liquid bridges in random granular materials. Journal of Colloid and Interface Science, 319, 182-192.

Guérif, J., Richard, G., Durr, C., Machet, J.M., Recous, S., Roger-Estrade, J., 2001. A review of tillage effects on crop residue management, seedbed conditions and seedling establishment. Soil Till. Res. 61, 13-32.

Hamblin, A., Tennant, D., 1979. Interactions between soil type and tillage level in a dryland situation. Aust. J. Soil Res. 17, 177-189.

Hamza, M.A., Anderson, W.K., 2005. Soil compaction in cropping systems: A review of the nature, causes and possible solutions. Soil Till. Res. 82, 121-145.

Hartmann, C., Poss, R., Singhatat, V., 1999. Soil compaction and plant growth in Northeast Thailand: The case of the Nam Pong soil serie. In: Natural Resources Management issues in the Korat Basin of Northeast Thailand, an Overview (eds S.P. Kam, C.T. Hoanh, G. Trebuil, B. Hardy). PP. 157-162. IRRI, Khon Kaen, Thailand.

Hartmann, C., Poss, R., Noble, A.D., Jongskul, A., Bourdon, E., Brunet, D., Lesturgez, G., 2008 a. Subsoil improvement in a tropical coarse textured soil: Effect of deep-ripping and slotting. Soil Till. Res. 99, 245-253.

Hartmann, C., Lesturgez, G., Sindhusen, P., Ratana-Anupap, S., Hallaire, V., Bruand, A., Poss, R., 2008b. Consequences of slotting on the pore characteristics of a sandy soil in northeast Thailand. Soil Use and Management, 24, 100-107.

Herminghaus, S., 2005. Dynamics of wet granular matter. Advances in Physics, 54, 221-261.

Horn, R., Domzal, H., Slowinska-Jurkiewicz, A., van Ouwerkerk, C., 1995. Soil compaction 
processes and their effects on the structure of arable soils and the environment. Soil Till. Res. $35,23-36$.

Hornbaker, D., Albert, R., Albert, I., Barabasi, A., Schiffer, P., 1997. What keeps sandcastles standing? Nature $387,765$.

Iveson, S.M., Beathe, J.A., Page, N.W., 2002. The dynamic strength of partially saturated powder compacts: the effect of liquid properties. Powder Technology, 127, 149-161.

Kawamoto, K., Mashino, S., Oda, M., Miyazaki, T., 2004. Moisture structures of laterally expanding fingering flows in sandy soils. Geoderma 119, 197-217.

Kemper, W., Rosenau, R., 1984. Soil cohesion as affected by time and water content. Soil Science

Kozlowski, T., 1999. Soil compaction and growth of woody plants. Scand. J. For. Res. 14, 596-619.

Le Bissonnais, Y., Renaux, B., Delouche, H., 1995. Interactions between soil properties and moisture content in crust formation, runoff and interrill erosion from tilled loess soils. Catena, Society of America Journal, 48, 1001-1006.

Kohonen, M., Geromichalos, D., Scheel, M., Schier, C., Herminghaus, S., 2004. On capillary bridges in wet granular materials. Physica A: Statistical Mechanics and its Applications, 339, $7-15$. $25,33-46$.

Lesturgez, G., Poss, R., Hartmann, C., Bourdon, E., Noble, A., Ratana-Anupap, S., 2004. Roots of Stylosanthes hamata create macropores in the compact layer of a sandy soil. Plant Soil 260, 101-109.

Mead, J.A., Chan, K.J., 1988. Effect of deep tillage and seedbed preparation on the growth and yield of wheat on a hard-setting soil. Aust. J. Exp. Agr. 28, 491-498.

Meek, B.D., Rechel, E.A., Carter, L.M., Detar, W.R., 1988. Soil compaction and its effect on alfalfa in zone production systems. Soil Sci. Soc. Am. J. 52, 232-236. 
1 Meek, B., Rechel, E., Carter, L., DeTar, W., 1992. Bulk density of a sandy loam: Traffic, tillage, and irrigation-method effects. Soil Sci. Soc. Am. J. 56, 562-565.

3 Mitarai, N., Nori, F., 2006. Wet granular materials. Adv. Phys. 55, 1-45.

4 Moffat, A.J., Boswell, R.C., 1997. The effectiveness of cultivation using the winged time on restored sand and gravel workings. Soil Till. Res., 40, 111-124.

6 Mullins, C.E., Macleod, D.A., Northcote, K.H., Tisdall, J.M., Young, I.M., 1990. Hardsetting soils: Behavior, occurrence, and management. In: Lal, R., Stewart, B.A. (Eds.), Advances in soil science, vol. 11, soil degradation. Springer-Verlag, New York, pp. 37-108.

9 Mullins, C.E., Panayiotopoulos, K.P., 1984. The strength of unsaturated mixtures of sand and

11 Mwendera, E.J., Feyen, J., 1994. Effects of tillage and rainfall on soil surface roughness and properties. Soil Technol. 7, 93-103.

13 Ndiaye, B., Esteves, M., Vandervaere, J.P., Lapetite, J.M., Vauclin, M., 2005. Effect of rainfall and tillage direction on the evolution of surface crusts, soil hydraulic properties and runoff generation for a sandy loam soil. J. Hydrol. 307, 294-311.

16 Nimmo, J.R., Akstin, K.C., 1988. Hydraulic conductivity of a sandy soil at low water-content after compaction by various methods. Soil Sci. Soc. Am. J. 52, 303-310.

Or, D., Ghezzehei, T.A., 2002. Modeling post-tillage soil structural dynamics: A review. Soil Till. Res. 64, 41-59.

Osunbitan, J.A., Oyedele, D.J., Adekalu, K.O., 2005. Tillage effects on bulk density, hydraulic conductivity and strength of a loamy sand soil in Southwestern Nigeria. Soil Till. Res. 82, 57-64.

Panayiotopoulos, K.P., Mullins, C.E., 1985. Packing of sands. Journal of Soil Science, 36, 129-139. 
1 Panayiotopoulos, K.P., 1989. Packing of sands-a review. Soil and Tillage Research, 13, 101-121.

2 Pierrat, P., Caram, H.S., 1997. Tensile strength of wet granular materials. Powder Technology, 91, 3 83-93.

4 Roth, C.H. 1997. Bulk density of surface crusts: depths functions and relationships to texture. Catena, 29, 223-237.

6 Rudolph, A., Helming, K., Diestel, H., 1997. Effect of antecedent soil water content and rainfall regime on microrelief changes. Soil Technol. 10, 69-81.

Scheel, M., Seemann, R., Brinkmann, M., Di Michiel, M., Sheppard, A., Breidenbach, B., Herminghaus, S., 2008. Morphological clues to wet granular pile stability. Nature Materials,

Soane, B.D., Blackwell, P.S., Dickson, J.W., Painter, D.J., 1981a. Compaction by agricultural vehicles: A review. 2: Compaction under tyres and other running gear. Soil Till. Res. 1, $373-400$.

Soane, B.D., Blackwell, P.S., Dickson, J.W., Painter, D.J., 1981b. Compaction by agricultural vehicles: A review. 1. Soil and wheel characteristics. Soil Till. Res., 207-237.

Soane, B.D., Dickson, J.W., Campbell, D.J., 1982. Compaction by agricultural vehicles: A review, 3: Incidence and control of compaction in crop production. Soil Till. Res. 2, 3-36.

Soane, B.D., 1990. The role of organic matter in soil compactibility: A review of some practical aspects. Soil Till. Res. 16, 179-201.

Soane, B.D., van Ouwerkerk, C., 1995. Implications of soil compaction in crop production for the quality of the environment. Soil Till. Res. 35, 5-22.

Soane, B.D., Ball, B.C., 1998. Review of management and conduct of long-term tillage studies with special reference to a 25-yr experiment on barley in Scotland. Soil Till. Res. 45, 17-37.

Soulie, F., El Youssoufi, M.S., Cherblanc, F., Saix, C., 2006. Capillary cohesion and mechanical 
strength of polydisperse granular materials. European Physical Journal E, 21, 349-357.

2 Twomlow, S., Bruneau, P., 2000. The influence of tillage on semi-arid soil-water regimes in 3 zimbabwe. Geoderma 95, 33-51.

4 Willett, C.D., Adams, M.J., Johnson, S.A., Seville, J.P.K., 2000. Capillary Bridges between Two $5 \quad$ Spherical Bodies. Langmuir, 16, 9396-9405.

6 Wilton, B., 1964. Effect of cultivations on the level of the surface of a soil. J Agr. Eng. Res. 9, 7 214-219.

8 Young, I.M., Mullins, C.E., Costigan, P.A., Bengough, A.G., 1991. Hardsetting and structural 9 regeneration in two unstable British sandy loams and their influence on crop growth. Soil Till. 10 Res. 19, 383-394. 


\section{$1 \quad$ Legend of the figures}

3 Fig. 1. Rainfall distribution and accumulated rainfall (AR) in Exp.1 and Exp.2. DAP is day after tillage for Exp.1, 4 which started from 25 May 2007. DAP' is day after tillage for Exp.2, which started from 6 July 2007.

6 Fig. 2. Matric potential of a) Top: D (40 cm tillage) under furrow ( $\longrightarrow$ ) and under ridge ( $\longrightarrow-$ ); b) Bottom: $\mathrm{S}$ (under furrow). Average values $(n=3)$ are shown.

9 Fig.3. Soil surface level recorded in Exp.1, example of one subplot; left side is DAP4 and right side is DAP60. 10 Measurements were made along a regular grid $5 \times 5 \mathrm{~cm}$ (i.e. 361 measurement points).

12 Fig.4. Mean soil height with cumulated rainfall. D and $\mathrm{S}$ are Deep $(40 \mathrm{~cm})$ and $\mathrm{S}$ shallow $(20 \mathrm{~cm})$ tillage 13 respectively; $\mathrm{W}$ and $\mathrm{Y}$ indicate tillage made in wet and dry soil respectively. Each line is one replicate from the 14 subplot. The numbers indicate mean values of level decrease with standard errors in the brackets. Note: The 15 reference level was the board arm that support lasermeter. The arm was fixed with iron sticks fixed deep in the 16 soil. The absolute value of soil height was not important, but the relative soil height that measured at different time was our aim.

19 Fig. 5. Bulk density collected under furrow after major rainfall events during Exp.1 and Exp.2. D and S are Deep $20(40 \mathrm{~cm})$ and $\mathrm{S}$ shallow $(20 \mathrm{~cm})$ tillage respectively $(\mathrm{n}=5) ; \mathrm{W}$ and $\mathrm{Y}$ indicate tillage made in wet and dry soil 21 respectively ( $\mathrm{n}=9$ ). DAP and DAP' are the number of days after tillage for Exp.1 and Exp.2 respectively; AR is 22 the accumulated rainfall since tillage day. Error bar indicates standard error of mean (SEM).

24 Fig.6. a) Soil infiltration rate decreased with added water amount, b) Soil surface level change with added water amount. The soil was protected from rainfall under plastic before tillage. Error bars indicate standard error of means ( $\mathrm{n}=9$ ). $\mathrm{D}-\mathrm{f}$ is deep flooding; $\mathrm{S}-\mathrm{f}$ is shallow flooding. 
1 Fig. 7. Bulk density after flooding. $200 \mathrm{~mm}$ water was added into "D-f" and $100 \mathrm{~mm}$ water into "S-f". Error bar 2 indicates standard error of mean (SEM) $(n=9)$. D-f is deep flooding; $\mathrm{S}-\mathrm{f}$ is shallow flooding. 3

4 Fig.8. Schematic diagram of possible slumping dynamic profiles in tilled sandy soil. a) just after tillage, b) beginning of slumping, $\mathrm{c}$ ) with maximum bulk density at surface and deeper layer, d) a comparison profile after

6 mechanical compaction, maximum bulk density occurs in the intermediate layer. 
DAP-Exp.1

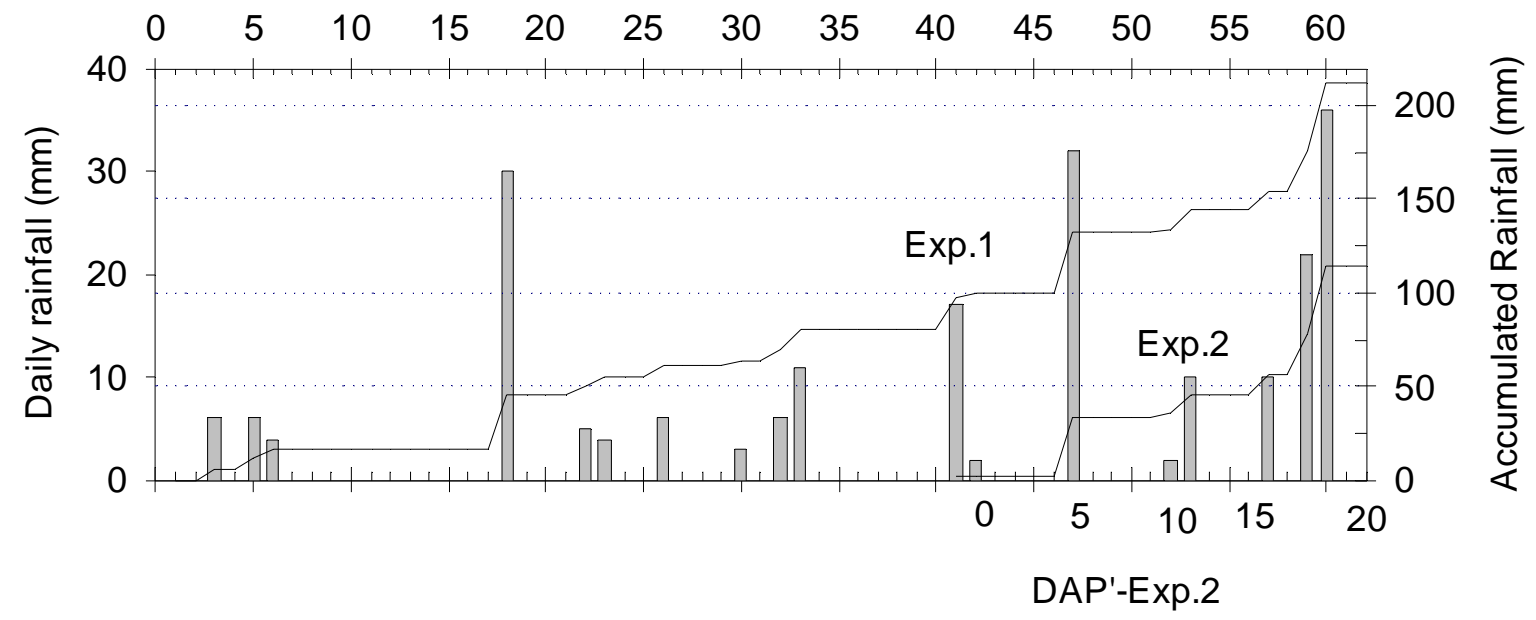

3 Fig. 1 
a)

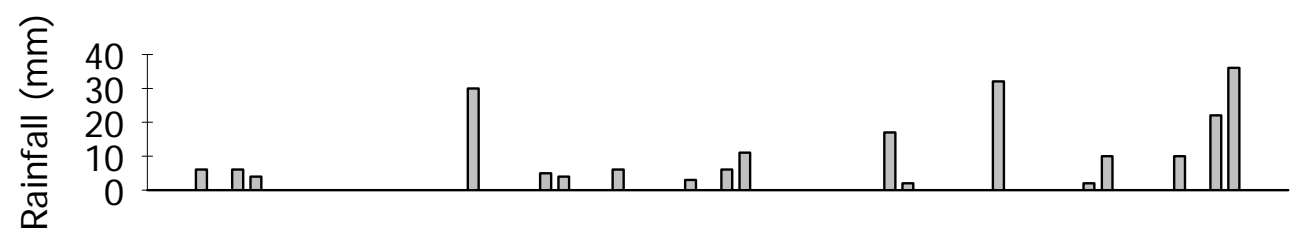

Days after ploughing (DAP)

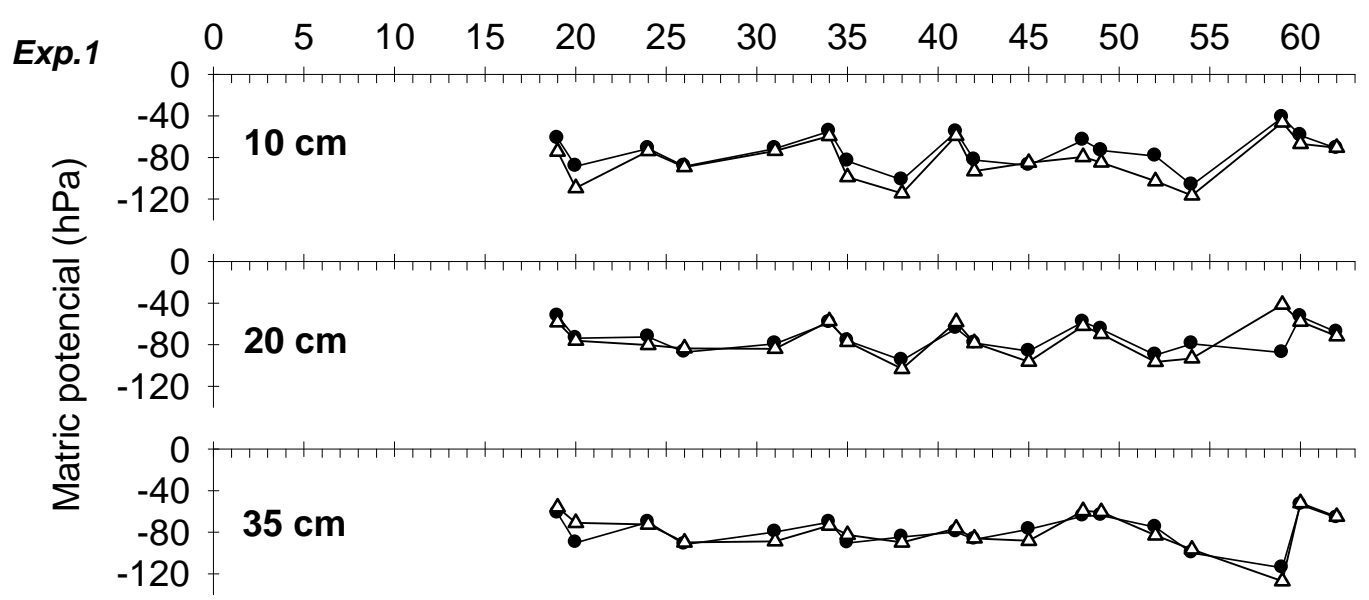

Exp.2

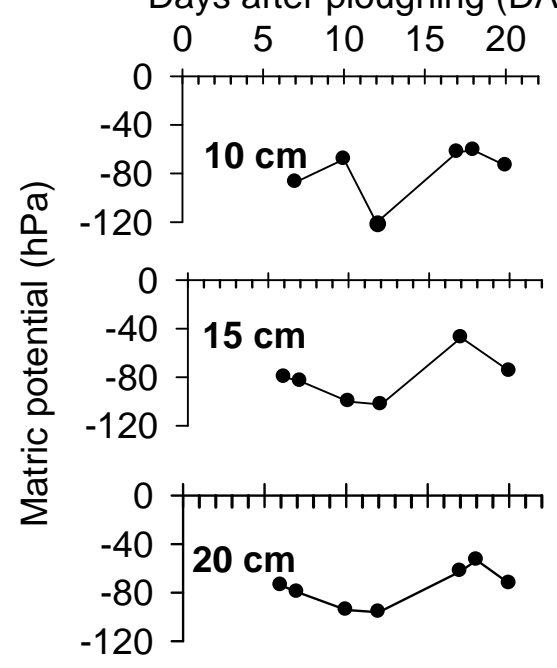

b)

Fig. 2 
1
2
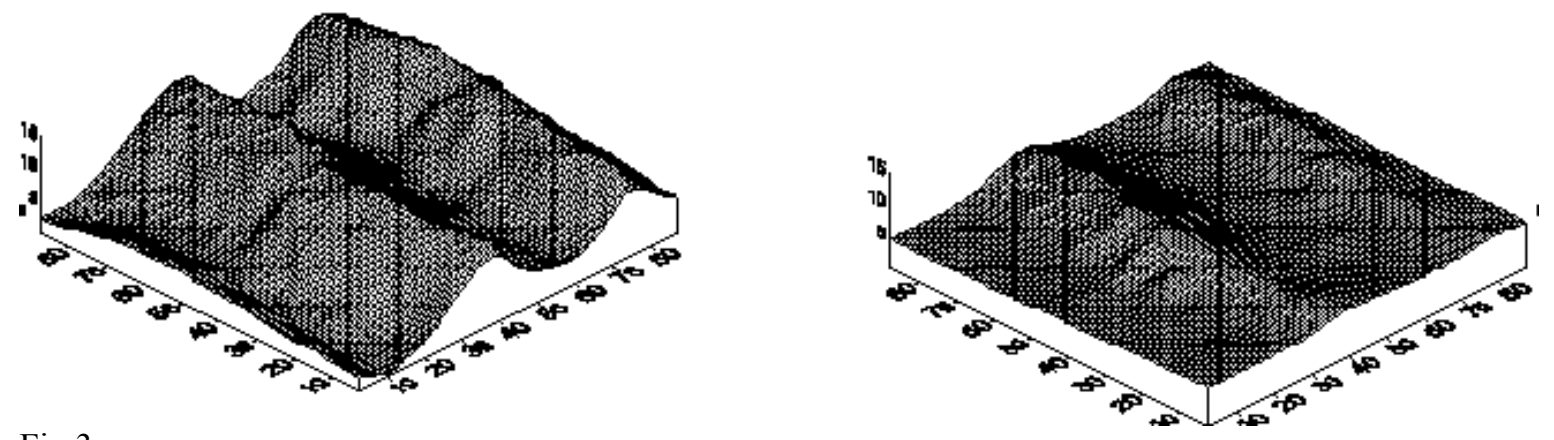

$\begin{array}{ll}3 & \text { Fig. } 3\end{array}$

30 
Exp.1

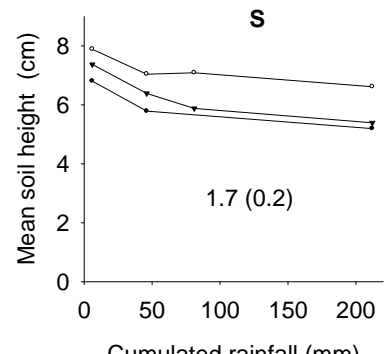

2

Fig.4
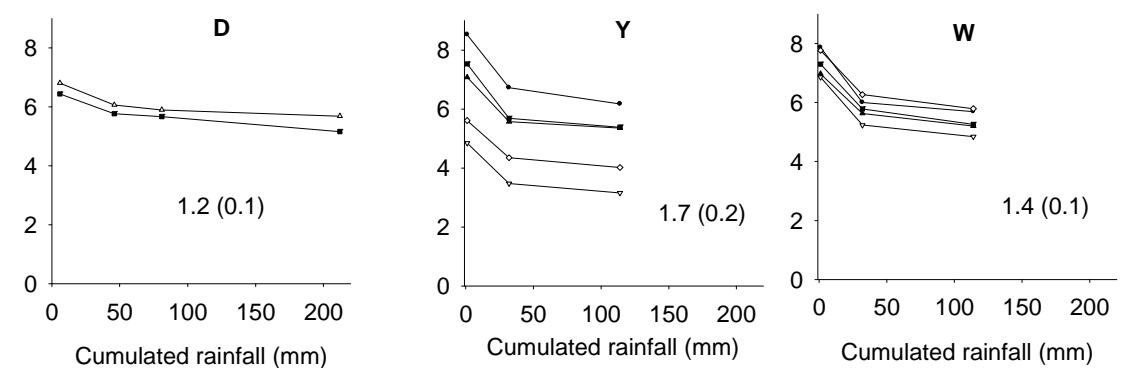
Exp.1

Bulk density $\left(\mathrm{g} \mathrm{cm}^{-3}\right)$

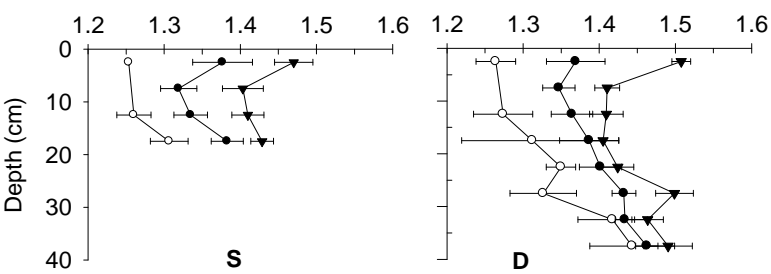

— DAP 6; AR $16 \mathrm{~mm}$

- DAP 49; AR $132 \mathrm{~mm}$

$\rightarrow$ DAP 60; AR $212 \mathrm{~mm}$
Exp.2

Bulk density $\left(\mathrm{g} \mathrm{cm}^{-3}\right)$

Bulk density $\left(\mathrm{g} \mathrm{cm}^{-3}\right)$

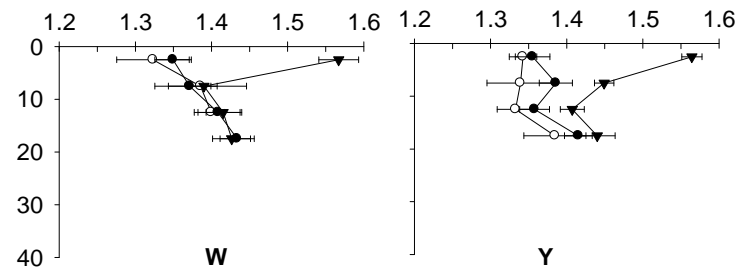

- DAP' 0, AR 2mm

- DAP' 6, AR 34 mm

$\checkmark$ DAP' 19, AR 114 mm

3 Fig. 5 


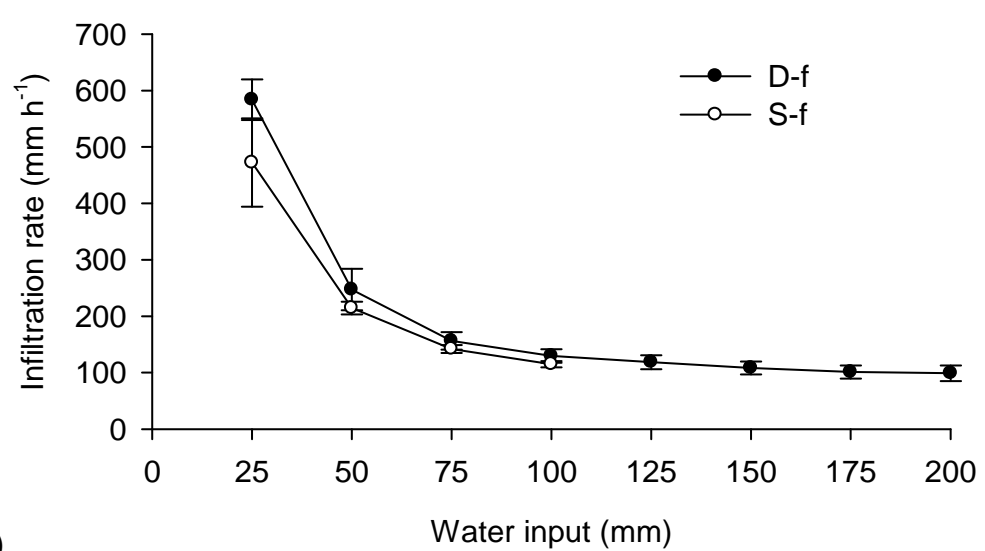

2 a)

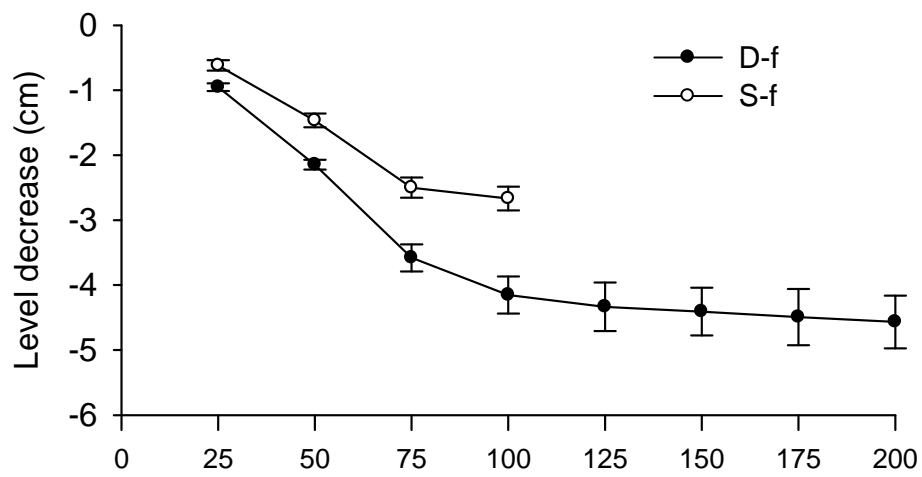

3 b)

Water input (mm)

$\begin{array}{ll}4 & \\ 5 & \text { Fig.6 }\end{array}$ 
1

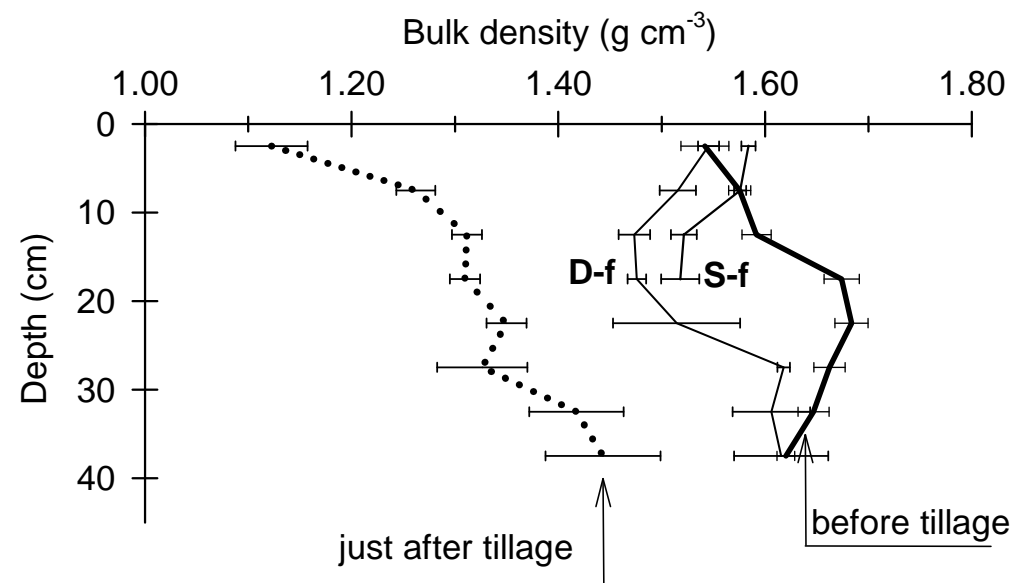

2

Fig. 7 
Bulk density

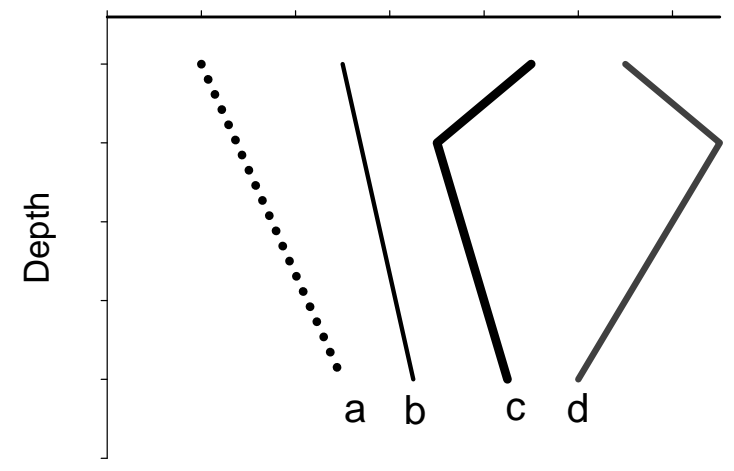

2

Bulk density

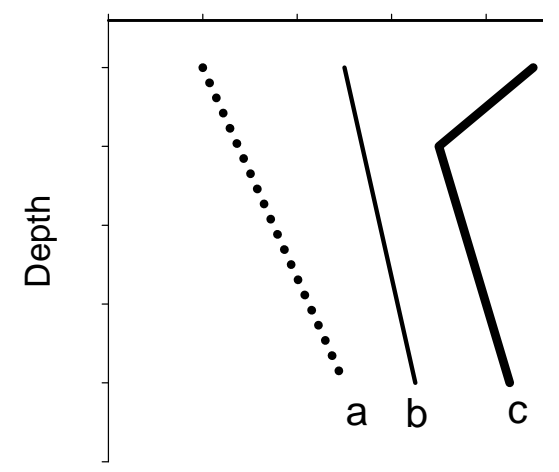

$\begin{array}{ll}3 & \\ 4 & \text { Fig.8 }\end{array}$ 


\section{Tables}

Table 1. Selected physical and chemical properties of soil measured one day before tillage.

\begin{tabular}{|c|c|c|c|c|c|c|c|}
\hline Depth & Sand (\%) & Silt (\%) & $\begin{array}{c}\text { Clay } \\
(\%)\end{array}$ & $\begin{array}{c}\text { Organic } \\
\text { mater }\end{array}$ & $\begin{array}{c}\text { Bulk } \\
\text { density }\end{array}$ & RP & SS \\
\hline$(\mathrm{cm})$ & $\begin{array}{c}50-2000 \\
\mu \mathrm{m}\end{array}$ & $\begin{array}{c}2-50 \\
\mu \mathrm{m}\end{array}$ & $<2 \mu \mathrm{m}$ & $\left(\mathrm{g} \mathrm{kg}^{-1}\right)$ & $\left(\mathrm{g} \mathrm{cm}^{-3}\right)$ & $(\mathrm{kPa})$ & $(\mathrm{kPa})$ \\
\hline $0-20$ & 90 & 9 & 1 & 4.5 & 1.60 & 13 & 4.6 \\
\hline $20-40$ & 86 & 11 & 3 & 4.6 & 1.65 & 33 & 5.6 \\
\hline $40-60$ & 86 & 11 & 3 & 1.9 & 1.62 & 32 & 5.1 \\
\hline
\end{tabular}

7

8 RP: Resistance to penetration, measured by datalogger penetrometer.

9 SS: Shear strength, measured by Hand Held Field Vane Shear Test (Helwany, 2007).

10

13 Table 2. Particle size distribution of soil $\left(\mathrm{g} \mathrm{kg}^{-1}\right)$ at $0-20 \mathrm{~cm}$ layer. It was measured by laser 14 diffraction granulometer (Malvern Instruments).

\begin{tabular}{|c|c|c|c|c|c|c|c|c|}
\hline & Clay & Silt & Sand & & & & & \\
\hline Size $(\mu \mathrm{m})$ & $0-2$ & $2-50$ & $50-100$ & $100-150$ & $150-200$ & $200-250$ & $250-500$ & $500-2000$ \\
\hline Content & 26 & 101 & 205 & 176 & 209 & 171 & 112 & 3 \\
\hline
\end{tabular}

